Updated 2013 and published in MAX PLANCK ENCYCLOPEDIA OF PUBLIC

INTERNATIONAL LAW, Rüdiger Wolfrum, ed., Oxford: Oxford University Press.

\title{
Postal Communications, International Regulation
}

\section{Mira Burri}

\section{A. Introduction}

\section{Historical Background}

1 Diverse systems for exchange of messages could be traced back to ancient Egypt, Greece, China, and the Roman Empire. Yet, postal communications, as we know them today, are of relatively recent origin. Their development was spurred on by advances in technology, most notably, printing, steam navigation, and railroads. As their importance for society grew, postal communications were centralized and became associated with the State.

2 In 1840, on the proposal of Sir Rowland Hill, the foundations of the modern postal service were laid in Great Britain with the introduction of the postage stamp and the uniform penny rate to be paid by the sender regardless of the distance travelled. Subsequently, the adhesive postage stamp system was adopted by other countries and its use spread to international mail as well.

\section{Evolution of Legal Rules}

3 International postal communications were originally governed by bilateral agreements, which corresponded to the particular needs of each State. However, the thereby evolving fragmented practice of varying rates, calculated in different currencies and units of weight, was highly inefficient, created obstacles to trade, and called for a co-ordination effort at the international level. 4 As a response, upon the initiative of the United States of America Postmaster-General, Montgomery Blair, an international meeting aiming at a common postal agreement was convened. Fifteen European and American States met in Paris on 11 May 1863 and, while failing to reach a common agreement, adopted a number of general principles which postal administrations were advised to consider when concluding conventions with other postal administrations. This was, however, only an interim solution until a more comprehensive body of rules was created at the international level, as established by the $1874 \rightarrow$ Universal Postal Union (UPU). The UPU presently counts 192 Member States. The latest amendments to the underlying regulatory 
Acts of the Union date back to the 25th UPU Congress that took place in Doha in 2012. The changes made are set to become effective on 1 January 2014.

\section{B. The Universal Postal Union (UPU)}

\section{Substantive UPU Rules}

\section{(a) Single Postal Territory and Freedom of Transit}

5 Pursuant to Art. 1 (2) UPU Constitution, the UPU aims 'to secure the organization and improvement of the postal services and to promote in this sphere the development of international collaboration'. For this purpose, as stated in Art. 1 (1) UPU Constitution, UPU member countries comprise a single postal territory for the reciprocal exchange of letter-post items. The concept of a single postal territory involves an obligation upon all Contracting Parties to treat letter-post items in transit from other countries as their own items, without discrimination (Art. 1bis (3) UPU Constitution).

6 Intrinsically related to the concept of single postal territory and equally fundamental to the functioning of the UPU is the principle of freedom of transit (Art. 1 (1) UPU Constitution). Freedom of transit is to be guaranteed throughout the entire territory of the Union and involves the obligation for an intermediate Member State to ensure the transport of postal items passed on to it in transit for another member country are provided with similar treatment to that given to domestic items (Art. 1bis (4) UPU Constitution). Art. 4 Universal Postal Convention ('UPC') specifies further that the freedom of transit carries with it the obligation for each Member State to ensure that its designated operators forward, always by the quickest routes and the most secure means which they use for their own items, closed mails and à découvert letter-post items which are passed to them by another designated operator.

7 The principles of a single postal territory and of freedom of transit do not, however, mean that countries are obliged to open their frontiers to transport organized by another country, nor do they derogate from the right to a national postal monopoly or the payment of transit charges. The concept of a single postal territory allows, however, for the facilitation and improvement of international mail exchanges through the established common rules and standards within it, ranging from the definition of a postage stamp (Art. 8 UPC) to customs matters and the prohibition of exchanging certain substances and items (Art. 15 UPC).

8 For the achievement of the above principles, UPU member countries are obliged, according to Art. 12 UPC, to ensure the provision of certain basic services. The latter cover the acceptance, handling, conveyance, and delivery of letter-post items and postal parcels within specified categories and up to specified units and/or weight. Next to these basic services, Art. 13 UPC provides for some mandatory and optional supplementary services, the former being above all related to the registration of in- and outbound letter-post items. 


\section{(b) Universal Service}

9 Art. 3 UPC contains the key obligation of UPU members to ensure that all users/customers enjoy the right to universal postal service involving the permanent provision of quality basic postal services at all points in their territory, at affordable prices. Member countries must thus establish within the framework of their national postal legislation or by customary means, the scope of the postal services offered and the requirement for quality and affordable prices. Member countries otherwise retain full discretion in defining universal service and could take into account the specific national conditions. While the form or the number of operators responsible for providing the universal postal service is not specified, UPU member countries must ensure that the offers of postal services and quality standards are achieved by the operator(s) in question.

\section{(c) Charges, Transit Charges, and Terminal Dues}

10 For the purpose of coordinating international mail exchanges, UPU member countries have agreed upon unified systems for postal charges, transit charges, and terminal dues, including procedural rules for their collection. These are normally expressed in Special Drawing Rights (SDR), which is the accounting unit of the $\rightarrow$ International Monetary Fund (IMF), also accepted as a monetary unit of the UPU (Art. 7 UPU Constitution).

11 Pursuant to Art. 6 UPC, the charges for the various international postal and special services are to be set by the Member States or their designated operators, depending on national legislation, in accordance with the UPC and the Regulations, and must in principle be related to the costs of providing these services. It is further stipulated that the international rates may not be lower than the domestic ones for the same types of item. The Member States of origin or its designated operator, depending on national legislation, fix the postage charges for the conveyance of letter- and parcel-post items throughout the entire single postal territory, including the delivery of these items, taking into account the guideline charges as provided in Arts 105 to 106 Letter Post Regulations. Except where otherwise provided, each designated operator retains the charges, which it has collected. Art. 205 Letter Post Regulations specifies further the components for the calculation of transit charges as remuneration for the services rendered in respect of land, sea, and air transit by the designated operator (Art. 32 UPC).

12 Each designated operator receiving letter-post items from another designated operator has the right to collect from the dispatching designated operator a payment for the costs incurred for the international mail received (Art. 27 UPC). For the application of the provisions on payment of terminal dues, the UPC establishes a specific classification as drawn up by the UPU Congress in its Resolution C 18/2008. Thereby, all UPU Member States are distributed into five groups, which are indicative of their terminal dues payment 
status and their benefit from and contribution to the UPU Quality of Service Fund (Art. 31 UPC). The new classification is a more nuanced version of the previously existing dual system where the so-called target system applied to international mail flows between industrialized countries and the transitional system to flows to, from, and between $\rightarrow$ developing countries. The essential difference between the two is that terminal dues charged under the target system are largely based on actual costs, whereas terminal dues charged under the transitional system are based on world average costs, thus entailing a preferential treatment for developing countries. Pursuant to the new categorization introduced by Resolution C 18/2008, which is to be reviewed every four years as of 2010, more States can benefit from the transitional system and from the Quality of Service Fund, at least for the initial period from 2010 to 2013.

\section{Regional Postal Agreements}

13 In addition to the UPU as the prime organization tackling international postal services issues, a number of regional bodies dealing with specific aspects of postal services have emerged. The rules created within these organizations are not in conflict with the law of the UPU, which explicitly allows the establishment of restricted unions and special agreements regarding international postal services, provided that they do not introduce provisions less favourable to the public than those provided for by the Acts of the UPU to which the States concerned are parties (Art. 8 UPU Constitution). As the latter rule concerns above all the provisions governing relations between the designated operators and the users of the Post, the possibility of 'contracting out' in the relations between administrations remains and is widely applied in practice, in particular as regards reduction of rates and transit charges. Currently, there are world-wide 17 restricted unions, amongst which, for instance, are the African Postal Union ('APU'), the Association of European Public Postal Operators ('POSTEUROP'), and the European Conference of Postal and Telecommunications Administrations ('CEPT'). The regional agencies increasingly play an important role in the implementation of the UPU's strategies and seek to do so accounting for specificities of the particular region (UPU Doha Postal Strategy).

\section{The General Agreement on Trade in Services (GATS)}

\section{Scope of Application}

14 Contemporary postal services as a means of communication play a crucial role for the fostering of $\rightarrow$ globalization processes, on the one hand, and constitute an important services sector in themselves, on the other (see also $\rightarrow$ Services, Trade in). Because of both these intrinsic features of postal services, they have become subject to the international trade rules, which emerged after 
World War II. Especially since the creation of the $\rightarrow$ World Trade Organization (WTO) in 1994 and the establishment of multilateral regulation in the field of services, the significance of this body of rules is ever growing, being particularly strengthened by the availability of dispute settlement $(\rightarrow$ World Trade Organization, Dispute Settlement) and enforcement mechanisms ( $\rightarrow$ World Trade Organization, Enforcement System). International trade rules have also better reflected the changed dynamics of the postal sector, defined, amongst other things, by commercialization of the State-owned enterprises, increased liberalization, and intensified competition.

15 While the rules of the GATT, the $\rightarrow$ General Agreement on Tariffs and Trade (1947 and 1994) have a certain bearing on international postal services, eg, as a measure restricting trade in products (WTO Panel Report CanadaCertain Measures Concerning Periodicals paras 5.31-5.39), the WTO rules of most immediate relevance for the postal services sector are those of the GATS, the $\rightarrow$ General Agreement on Trade in Services (1994).

16 The GATS, like the GATT, is aimed at protecting equality of competitive opportunities for companies in domestic markets, regardless of their origin and the origin of their services, and at facilitating the progressive liberalization of these markets. The GATS applies to all measures by WTO members affecting trade in services (Art. I (1) GATS). Such a measure is any measure of a binding nature taken by a government or authority, regardless of their hierarchical level within the WTO member, or a non-governmental body if the latter exercises powers delegated by a government or authority (Arts I (3) and XXVIII (a) GATS). For the purposes of the GATS, such measures are relevant only if they have an effect on the supply, supplier or consumption of a service. Trade in services under the GATS means the supply of services in one of four modes: a) cross-border supply; b) consumption abroad; c) commercial presence; and d) presence of natural persons of one WTO member in the territory of any other WTO member (Art. I (2) GATS).

17 Quite importantly for the postal services context, the GATS does not cover services supplied in the exercise of governmental authority (Art. I (3) (b) GATS). This exception requires two criteria to be met: a) the supply of the service in question must not be based on commercial considerations; and b) the service is supplied by a sole supplier (Art. I (3) (c) GATS).

18 The GATS covers any service in any sector. The WTO 'Services Sectoral Classification List' (MTN.GNS/W/120 [10 July 1991]), used as a template for the classification of services sectors and sub-sectors and largely relied upon by WTO members for their corresponding specific commitments, expressly includes 'Postal Services' and 'Courier Services' as separate categories, together with 'Telecommunication Services' and 'Audiovisual Services' under the heading 'Communication Services'. Postal services are cross-referenced to the provisional United Nations Central Product Classification (UNCPC Series M No 77 1991) containing four sub-items, most notably, under the explicit presumption that all of them are services supplied by national postal administrations. The latter qualification is missing under 'Courier Services', albeit covering almost identical services. 


\section{Pertinent GATS Provisions}

19 The GATS incorporates the principle of most-favoured-nation ('MFN') $(\rightarrow$ Most-Favoured-Nation Clause), which applies irrespective of the specific commitments made by a WTO member (Art. II (1) GATS). In essence, the MFN principle requires that a WTO member does not discriminate against services and service suppliers of any other WTO member, either de jure or de facto (WTO Appellate Body Report European Communities-Regime for the Importations, Sale and Distribution of Bananas para. 234), provided that the services and service suppliers in question are alike. Their likeness is to be determined on a case-by-case basis (WTO Appellate Body Report JapanTaxes on Alcoholic Beverages) against diverse factors, which demonstrate whether or not the services and service suppliers concerned are in a competitive relationship (WTO Appellate Body Report United States-Transitional Safeguard Measure on Combed Cotton Yarn from Pakistan para. 97). Unlike under the GATT, the GATS allows for flexibility in the application of MFN, and WTO members may specify that the MFN principle would not be applicable to certain measures, provided that those are listed in and meet the conditions of the Annex on Article II Exemptions (Art. II (2) GATS). No such exemptions for postal services have been made and this opportunity, which was limited until the date of entry into force of the WTO Agreement, ie 1 January 1995 , has now expired.

20 WTO members may undertake specific commitments on market access and national treatment $(\rightarrow$ National Treatment, Principle) regarding certain services sectors and sub-sectors and inscribed in their schedules of specific commitments. In the case of a market access commitment, services/service suppliers of any other WTO member must not be discriminated against (Art. XVI GATS). In the case of a national treatment commitment, services/service suppliers of any other WTO member must enjoy equal conditions of competition as domestic services/service suppliers (Art. XVII GATS). WTO members may, however, limit, condition or qualify their commitments on market access and national treatment (Art. XX GATS). To date, a total of 54 WTO members have made commitments for courier services and/or postal services. However, most of the commitments are for courier services exclusively and only 13 members (counting all European Union Member States as one member) have made commitments to postal services, the bulk of which are from the newly accessed States (WTO Postal and Courier Services).

21 Art. VI GATS laying down certain minimum standards of treatment regarding domestic regulation of trade in services, as well as Art. VIII GATS specifying that monopoly or exclusive rights service suppliers should not act in a manner inconsistent with MFN and the member's specific commitments, may also be found of relevance to specific postal services situations. However, considering the low level of commitments in the postal sector, their effect is presently modest. 


\section{Doha Round Developments}

22 In the framework of the WTO, members are obliged to "enter into successive rounds of negotiations... with a view to achieving a progressively higher level of liberalization' (Art. XIX:1 GATS). In the ongoing round of negotiations, the so-called $\rightarrow$ Doha Round, which commenced in 2001, some changes pertinent to the regulation of postal services have been envisaged.

23 Next to the hoped-for increased level of commitments for market access and national treatment and reduced limitations, the changes concern above all the future classification of postal and courier services (WTO Report by the Chairman to the Trade Negotiations Committee). While these are currently separate categories within the Sectoral Classification List, the distinction between them has increasingly become outdated in light of recent structural developments in the postal sector and the repositioning of State-owned postal companies as commercial players (WTO Communication from Switzerland, GATS 2000: Postal and Courier Services).

24 To remedy this situation, the US suggested that a new sub-sector within the sector 'Communication Services' be created that would exclusively cover express delivery services (WTO Communication from the United States, Express Delivery Services). The proposal submitted by the European Communities ('EC') and their Member States is more comprehensive and suggests that the hitherto separate sub-sectors of postal and courier services merge into one common sub-sector, which would also cover express delivery services (WTO Communication from the European Communities and their Member States, GATS 2000: Postal/Courier Services). A joint compromise proposal attempts to capture the common denominator of the two classification approaches by putting forward scheduling guidelines for specific commitments on postal, courier, and express delivery services, regardless of how they are classified (WTO Communication from the European Communities, Hong Kong China, Japan, New Zealand, Switzerland and the United States: Guidelines for Scheduling Commitments Concerning Postal and Courier Services, Including Express Delivery).

25 The European Union ('EU') has also proposed as an additional commitment (Art. XVIII GATS) a 'reference paper' for postal, courier, and express delivery services, which similarly to the 'reference paper' for basic telecommunication services ( $\rightarrow$ Telecommunications, International Regulation) would encompass regulatory principles for the prevention of anti-competitive practices by dominant suppliers, the administration of universal service obligation, licensing procedures, as well as the establishment of an independent regulatory authority (WTO Communication from the European Communities and their Member States: Proposal for a Reference Paper). It is yet to be seen whether and which of these proposals would effectively materialize post-Doha, as the round is presently stalled for reasons stemming from controversies other than the postal services sector. 


\section{Relationship between the UPU and the WTO}

26 In 2006, the UPU obtained ad hoc observer status to the WTO Council for Trade in Services and is thereby invited to any session of the Council whose agenda includes an item in relation to postal services (see also $\rightarrow$ International Organizations or Institutions, Observer Status). The Memorandum of Understanding on Cooperation between the two organizations, as submitted by the UPU in 2000, has not yet materialized. Resolution 40/2008, as agreed upon during the 2008 Geneva Congress, specifically instructs the UPU Council of Administration, in conjunction with the International Bureau, to monitor developments in the WTO service negotiations under the Doha Round relating to postal services, to keep members informed of these developments, and to provide information as to the compatibility between the UPU rules and those of the WTO.

27 In terms of norms conformity, neither the WTO nor the UPU frameworks contain rules clarifying the relationship between them. It is nonetheless certain that the rules created in the realm of the UPU are measures by WTO members within the meaning of the GATS inasmuch as UPU member countries are WTO members. Equally, State measures implementing the UPU rules at the domestic level and measures by postal administrations or private designated operators (in the exercise of powers delegated by a government or authority) implementing the UPU rules are measures by WTO members in the sense of the GATS, when UPU member countries are WTO members as well. A few delegations, including Canada, New Zealand, the European Union, and its Member States, made explicit declarations on signing the Acts of the 24th Congress in 2008 and of the 25th Congress in 2012, stating therewith that their countries will apply the Acts adopted by the UPU Congress in accordance with their obligations pursuant to the GATS, thus in effect giving some priority to the latter.

\section{Evaluation and Outlook}

28 Historically, postal services were organized as State monopolies with considerations of economies of scale and scope intrinsic to network-bound industries and the provision of universal service. The emergence and proliferation of new technologies, especially and most recently the $\rightarrow$ internet and other means of digital communication, have led to substantial diversification of communications markets and, while not necessarily reducing the significance of postal services, have certainly defined a need to modernize postal services and to restructure the postal services sector (UPU Congress Resolution C 17/2004 Markets Growth). In many countries, the traditional role of public postal administrations has been reconsidered, and markets previously reserved for the monopoly provider have been opened to competition. In some countries, such as New Zealand, Finland, and Sweden, the liberalization has been radical, while in others the process has developed incrementally with a gradual removal of certain services from the 'reserved' status, thus allowing for 
a readjustment of postal and courier service suppliers alike. Despite the widely acknowledged positive role of competition and the significant efficiency gains thereof, the mandate of public postal service to deliver quality postal services to the entire population at affordable prices remains vital and is unlikely to be rendered obsolete considering its contribution to social welfare.

29 This changed, and constantly changing, postal environment needs to be appropriately reflected in the international regulatory frameworks as well. While the rules created under the auspices of the UPU corresponded well to the national monopoly situation in sovereign States and provided for coordination and co-operation in international mail exchange, postal services now play an increasing role as economic assets. In the latter context, the framework of international trade rules established by the WTO and in particular the GATS may present a more adequate basis for the liberalization and globalization of the postal services sector.

30 As the liberalization process of national postal services markets proceeds at different speeds - for instance, while the US has generally been a leader in market opening, the US Postal Service still remains immune to antitrust law (United States Postal Service, Petitioner v Flamingo Industries [USA] Ltd United States Supreme Court [Washington DC 25 February 2004] 540 US 736) - there will be a need for flexibility of international rules that simultaneously promote further market liberalization and ensure a stable regulatory environment. In light of this, the need for international co-operation and coordination is indeed enhanced, on the one hand, and a certain adjustment of the international frameworks is required, on the other.

31 This adjustment will undoubtedly involve new and/or clearer definitions of postal, courier, logistics, and transport services $(\rightarrow$ Traffic and Transport, International Regulation), whose boundaries have become blurred as a result of the recent technological, market, and regulatory developments (WTO Postal and Courier Services). Securing coherence between the UPU and the WTO rules - the EC proposal within the Doha negotiations suggests (S/CSS/W/61 [23 March 2001]), for instance, a transfer of the UPU rules into the GATS schedules, thus providing for uniformity and a dispute settlement mechanism to the sector-will also be fundamental for the future expansion of postal services as one of the major communication networks in today's information society.

32 The Doha Postal Strategy adopted by the 25th Universal Postal Congress in 2012 demonstrates that the UPU is aware of the challenges it faces and the need to adapt to the changing role of postal communications. Building upon the Nairobi Postal Strategy of 2010, it reiterates the importance of the digital and financial spheres, alongside the traditional physical, in the international postal networks. Linked to this the emphasis on innovation and the need to diversify illustrate a willingness to create a more market-responsive, interoperable and sustainable network. These goals however admirable are only broad lines of action and do not (yet) make any headway into redesigning the substantive international regulatory system for postal communications. The WTO framework and arrangements made in the proliferating bilateral and regional Preferential Trade Agreements $(\rightarrow$ Regional Trade Agreements) will thus 
increasingly define the global regulatory environment for postal communications.

\section{SELECT BIBLIOGRAPHY}

R Geddes 'Public Utilities' in B Bouckaert and G De Geest (eds), Encyclopaedia of Law and Economics (Edward Elgar Cheltenham 2000) 1162-205.

A Perrazzelli and PR Vergano 'Terminal Dues under the UPU Convention and the GATS: An Overview of the Rules and Their Compatibility' (2000) 23 Fordham International Law Journal 736-51.

D Geradin The Liberalization of Postal Services in the European Union (Kluwer The Hague 2002).

S Sinclair The GATS Implications for Postal Services: Remarks prepared for the Universal Postal Union Seminar 'Mind the GATS: Defining UPU Developing Country Interests in GATS Negotiations' (UPU Berne 2002).

A Alverno and A Levy 'The WTO Doha Development Agenda: Defining the Scope of Postal Service Liberalization' in MA Crew and PR Kleindorfer (eds) Competitive Transformation of the Postal and Delivery Sector (Kluwer London 2003) 199-222.

M Krajewski 'Public Services and Trade Liberalization: Mapping the Legal Framework' (2003) 6 JIEL 341-67.

MC Bronckers and P Larouche 'The WTO Regime for Telecommunications Services' in MC Bronckers and GN Horlick (eds) WTO Jurisprudence and Policy: Practitioners' Perspectives (Cameron May London 2004) 519-90.

D Geradin and M Kerf 'Levelling the Playing Field: Is the WTO Adequately Equipped to Prevent Anti-Competitive Practices in Telecommunications?' in D Geradin and D Luff (eds) The WTO and Global Convergence in Telecommunications and Audio-Visual Services (CUP Cambridge 2004) 130-62.

D Luff 'Current International Trade Rules Relevant to Telecommunications Services' in D Geradin and D Luff (eds) The WTO and Global Convergence in Telecommunications and Audio-Visual Services (CUP Cambridge 2004) 34-50.

PWJ de Bijl E van Damme and P Larouche 'Regulating Access to Stimulate Competition in Postal Markets?' in MA Crew and PR Kleindorfer (eds) Progress toward Liberalization of the Postal and Delivery Sector (Springer New York 2005) 153-72.

D Geradin and JG Sidak 'The Future of the Postal Monopoly: American and European Perspectives after the Presidential Commission and Flamingo Industries' (2005) 28 World Competition 161-91.

MA Crew and PR Kleindorfer (eds) Liberalization of the Postal and Delivery Sector (Edward Elgar Cheltenham 2006).

JB Goco 'Non-Discrimination, "Likeness" and Market Definition in World Trade Organization Jurisprudence' (2006) 40 JWT 315-40. 
EH Leroux "What is a "Service Supplied in the Exercise of Governmental Authority" under Article I:3(b) and (c) of the General Agreement on Trade in Services" (2006) 40 JWT 345-85.

P Van den Bossche The Law and Policy of the World Trade Organization (CUP Cambridge 2008).

MA Crew and PR Kleindorfer (eds) Competition and Regulation in the Postal and Delivery Sector (Edward Elgar Cheltenham 2008).

R Zhang 'Liberalization of Postal and Courier Services: Ready for Delivery?' in J Marchetti and M Roy (eds) Opening Markets for Trade in Services; Countries and Sectors in Bilateral and WTO Negotiations (CUP Cambridge 2008).

\section{SELECT DOCUMENTS}

Ecorys, Main Developments in the Postal Sector (2006-2008) (Ecorys Rotterdam 2008).

Marrakesh Agreement Establishing the World Trade Organization (adopted 15 April 1994, entered into force 1 January 1995) 1867 UNTS 154.

OECD Promoting Competition in Postal Services (OECD Paris 1999).

TMC Asser Instituut 'The Study of the Relationship between the Constitution, Rules and Practice of the Universal Postal Union, the WTO Rules (in Particular the GATS), and the European Community Law' (TMC Asser Instituut The Hague 2004).

UPU 'Background Note on Terminal Dues for the World Trade Organization' (UPU International Bureau Berne 2001).

UPU Constitution of the Universal Postal Union. General Regulations. With Commentary (UPU International Bureau Berne 2010).

UPU Doha Postal Strategy 2013-2016: The Global Roadmap for Postal Services (UPU International Bureau Berne 2012).

UPU Final Decisions of the 2012 Doha Congress (UPU International Bureau Berne 2013).

UPU Guide to Postal Reform and Development (UPU International Bureau Berne 2004).

UPU Impact on the Universal Postal Union (UPU) and its Members of the World Trade Organization (WTO) and its General Agreement on Trade in Services (GATS) (UPU International Bureau Berne 2001).

UPU Letter Post Manual (UPU International Bureau Berne 2009).

UPU Manual of the Postal Payment Services (UPU International Bureau Berne 2010).

UPU Parcel Post Manual (UPU International Bureau Berne 2010).

UPU Resolution C 18/2008 'Classification of Countries and Territories for Terminal Dues and Quality of Service Fund (QSF) Purposes’ (24th UPU Congress).

UPU Study of the Various Proposals Concerning the Classification of Postal Services and Courier Services Submitted to the World Trade Organization (WTO) (International Bureau of the UPU Berne 2005). 
WIK-Consult, The Role of Regulators in a More Competitive Postal Market (WIK Consult Bad Honnef 2009).

WTO Canada: Certain Measures concerning Periodicals-Report of the Panel (14 March 1997) WT/DS31/R.

WTO Communication from the European Communities and their Member States: Proposal for a Reference Paper (17 January 2005) TN/S/W/26.

WTO Communication from the European Communities, Hong Kong China, Japan, New Zealand, Switzerland and the United States: Guidelines for Scheduling Commitments Concerning Postal and Courier Services, Including Express Delivery (17 February 2005) $\mathrm{TN} / \mathrm{S} / \mathrm{W} / 30$.

WTO Communication from MERCOSUR and Bolivia: Postal Services (26 September 2001) S/CSS/W/108.

WTO Communication from New Zealand: Negotiating Proposal for Postal/Courier Services (6 November 2001) S/CSS/W/115.

WTO Communication from Switzerland: GATS 2000 Postal and Courier Services (14 May 2001) $\mathrm{S} / \mathrm{CSS} / \mathrm{W} / 73$.

WTO Communication from the United States: Express Delivery Services (18 December 2000) $\mathrm{S} / \mathrm{CSS} / \mathrm{W} / 26$.

WTO Doha Ministerial Declaration (14 November 2001) WT/MIN(01)/DEC/W/1.

WTO European Communities: Regime for the Importations, Sale and Distribution of Bananas-Appellate Body Report (9 September 1997) WT/DS27/AB/R.

WTO Japan: Taxes on Alcoholic Beverages-Appellate Body Report (1 November 1996) WT/DS8/AB/R; WT/DS10/AB/R; WT/DS11/AB/R.

WTO Postal and Courier Services: Background Note by the Secretariat (12 June 1998) $\mathrm{S} / \mathrm{C} / \mathrm{W} / 39$.

WTO Postal and Courier Services: Background Note by the Secretariat (11 August 2010) $\mathrm{SC} / \mathrm{W} / 319$.

WTO Council for Trade in Services Report by the Chairman to the Trade Negotiations Committee (28 November 2005) TN/S/23.

WTO Services Sectoral Classification List (10 July 1991) MTN.GNS/W/120.

WTO United States: Transitional Safeguard Measure on Combed Cotton Yarn from Pakistan-Appellate Body Report (5 November 2001) WT/DS192/AB/R.

Last updated: March 2013 